\title{
Energy Flow Through a Population of Richardson's Ground Squirrels
}

\author{
David A. ZEGERS ${ }^{1}$ \& Olwen WILLIAMS
}

Zegers D. A. \& Williams O., 1979: Energy flow through a population of Richardson's ground squirrels. Acta theriol., 24, 17: 221-235 [With 6 Tables \& 1 Fig.]

A mathematical model of energy flow was designed, and field data were gathered to determine the energetic role of Richardson's ground squirrel in its ecosystem from April 1974 to June 1976. Total energy flow decreased throughout the study period. Energy losses due to dispersal, weather or predation were greater in the summer of 1975 than in 1974. Losses during hibernation were less during the winter of 1975-76 than in the previous winter. The relationship of weather, predation and food supply to these changes is discussed. Daily energy budget $(D E B)$ for an individual of mean weight $(291.3 \mathrm{gm})$ was $35.49 \mathrm{kcal}$. $D E B$ comprised 1) $4.08 \mathrm{kcal}$ spent while above ground and not moving, 2) $4.48 \mathrm{kcal}$ spent above ground and moving, and 3) $26.93 \mathrm{kcal}$ spent in the burrow and not moving. Mean summer density decreased from $35.7 /$ ha in 1974 to 29.9 in 1975 . Density at arousal dropped from 25.0 in 1974 to 19.0 in 1975 to 15.4 in 1976 . Possible mechanisms of population regulation are reviewed.

[Dept. of Environmental, Population and Organismic Biol., Univ. Colorado, Boulder, Co 80309, USA].

\section{INTRODUCTION}

It is widely recognized that most of the energy flowing through an ecosystem passes through the detritus food chain without entering the grazing food chain. However, there remains much interest in and many unanswered questions concerning the role of small herbivorous mammals in temperate zone ecosystems (G olley et al., 1975; Petrusewicz $\&$ Grodziński, 1975). Hence, as part of an effort to determine the role of Richardson's ground squirrel, Spermophilus richardsonii elegans (S. elegans elegans, sensu $\mathrm{Nadler}, \mathrm{H}$ of $\mathrm{fmann}$ \& Greer, 1971) in a montane meadow ecosystem, we examined the energy flow through the population. Specifically, we attempted to devise a model illustrating this energy flow accurately and reliably.

1 Present address: Dept. of Biology, Millersville State College, Millersville, PA, USA 17551. 


\section{MATERIAL AND METHODS}

\section{Study Area}

All laboratory and computer work in this study was conducted at the University of Colorado, Boulder, Colorado, U.S.A. Field work was performed at a site on the eastern slope of the Front Range of the Rocky Mountains at a location approximately $16 \mathrm{~km}$ southwest of Boulder (NE 1/4 sec. 11 and NW 1/4 sec. 12, T1S, R72W, Tungsten Quadrangle). Our study site of 3.6 ha was located in a gently sloping, bowl-shaped, approximately 76 -ha meadow at $2440 \mathrm{~m}$ elevation. The site, grazed by horses, included both west- and south-facing slopes and several rocky outcrops.

The conspicuous plant taxa occupying the tract included Poa spp., Bromus spp.. Iris missouriensis, Thermopsis divaricarpa, Helianthus annuus, and Helianthella quinquenervis. The surrounding forests consisted mostly of stands of ponderosa pine (Pinus ponderosa), douglas fir (Pseudotsuga menziesii), and of lodgepole pine (Pinus contorta). A few, small stands of aspen (Populus tremuloides) were also in the vicinity.

\section{Model Construction}

Before other work began, a mathematical model of energy flow was constructed. Then values for the various model parameters were obtained from field, laboratory, and computer work. This model (Fig. 1) had two sections: 1) a model of energy

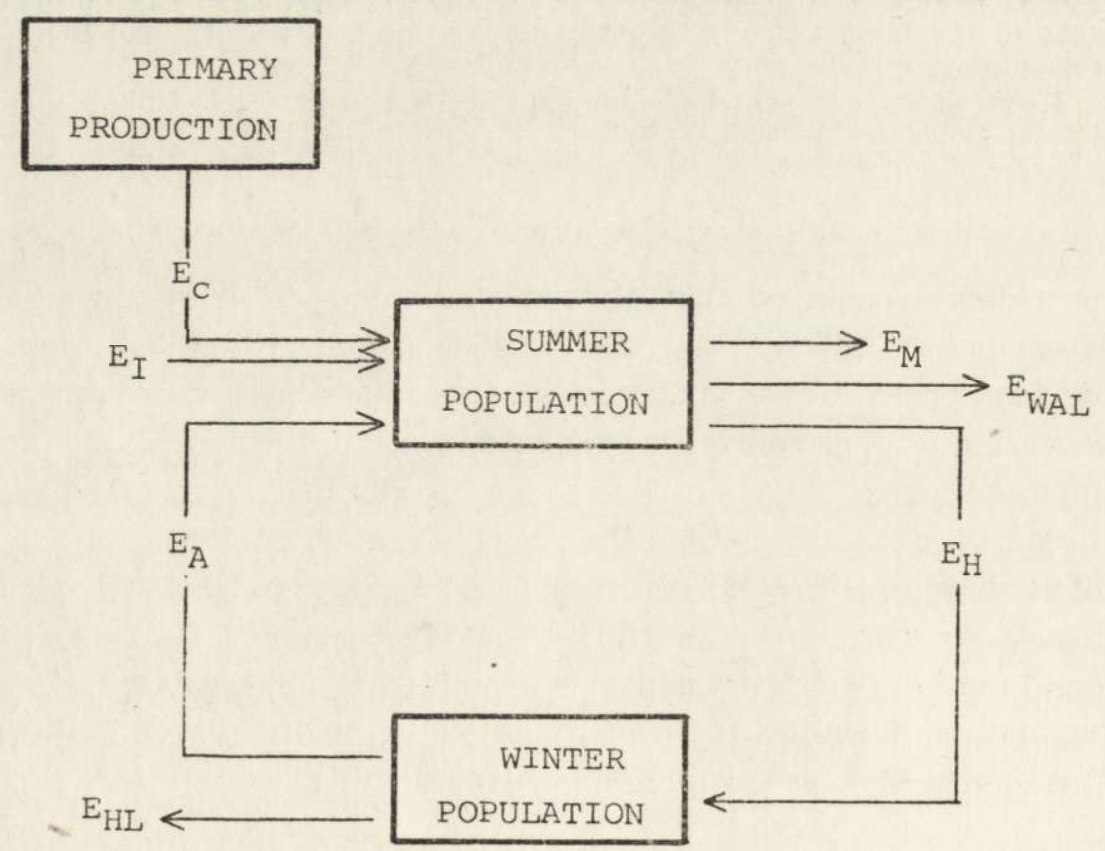

Fig. 1. Model of energy flow through a colony of Richardson's ground squirrels Spermophilus richardsonii elegans. Symbols are defined in text. 
flow during the active season, and 2) a model for the hibernating period. Energy flow during the active season was modeled by the following equation:

$$
E_{C}+E_{I}+E_{A}=E_{M}+E_{H}+E_{W A L}
$$

where $E_{C}$ is the energy gained by the population via consumption, $E_{I}$ is the energy gained from immigration, $E_{A}$ is the energy within the population (i.e. in the body tissues of individuals) upon arousal from hibernation, $E_{M}$ is the energy lost due to the collective metabolism of the individuals within the population during the active season, $E_{H}$ is the energy within the bodies when hibernation begins, and $E_{\text {/WAL }}$ is the energy lost due to the loss of whole animals during the summer (i.e. loss via predation and dispersal).

Energy flow during hibernation was described by the equation:

$$
E_{H}=E_{A}+E_{H L}
$$

where $E_{H}$ is the energy within the population when hibernation begins, $E_{A}$ is the energy remaining in the population upon arousing for the next active season, and $E_{H L}$ is the energy lost, due to metabolism and death, during hibernation. In general, data were gathered to directly determine all seven of the variables in equations 1 and 2 except that 1) $E_{C}$ was determined by solving Equation 1 for $E_{C}$ and 2) $E_{H L}$ was determined by solving Equation 2 for $E_{H L}$.

Basic to the measurement of $E_{M}$ is the daily energy budget (DEB) of the typical (i.e. average) individual. $D E B$, expressed as kcal/individual-day, is the number of kilocalories needed for maintenance during an average 24-hour period. In this study its measurement was slightly modified from that originally developed by Grodziński \& Górecki (1967). The squirrels' day was divided into three components: 1) in the burrow and not moving, 2) above ground and not moving, 3) above ground and moving. Metabolic rates for each of these situations were calculated using the following equation proposed by Wunder (1975):

$$
M R=\alpha(3.8 W-0.25)+1.05 W-0.50 \cdot\left[(38-4 W+0.25)-T_{A}\right]+(8.46 W-0.40) V
$$

where $W$ is weight (in grams), $\mathrm{T}_{\mathrm{A}}$ is ambient temperature $\left({ }^{\circ} \mathrm{C}\right.$ ) and $\mathrm{V}$ is velocity $(\mathrm{km} / \mathrm{hr})$. Next, the time typically spent in each one of these activities was determined (see section on Field Techniques). The following equation was then used to calculate $D E B$ :

$$
D E B=\left(H R_{M} \cdot M R_{M}+H R_{N} \cdot M R_{N}+H R_{B} \cdot M R_{B}\right) W_{M}
$$

where $H R_{M}$ is the mean time (in hours) spent moving and above ground, $M R_{M}$ is the metabolic rate estimated for the time spent moving above ground, $H R_{N}$ is the mean time spent not moving and above ground, $M R_{N}$ is the metabolic rate estimated for that time spent not moving and above ground, $H R_{B}$ is the mean time spent in the burrow and not moving, and $M R_{B}$ is the metabolic rate estimated for that time spent in the burrow and not moving.

Once $D E B$ was calculated, $E_{M}$ could be determined. The $E_{M}$ equation:

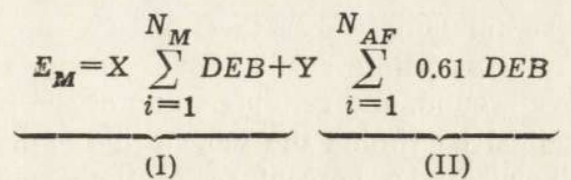

shows the energy loss to metabolism to be composed of two parts: (I) the loss due to the collective metabolism of all the individuals excluding losses due to 
reproduction, where $X$ is the length of the active season and $M_{M}$ is the mean density and (II) the loss due to reproduction, where $Y$ is the combined length of gestation and lactation and $N_{A F}$ is the density of reproducing females. To calculate the metabolic cost of reproduction several assumptions were made: 1) reproduction was assumed not significantly to increase energy expenditure for males, 2) the increased expenditure for females was limited to the periods of gestation and lactation, and 3) this increased expenditure was similar to that of the only other rodents studied: Clethrionomys glareolus. Mus musculus and Microtus arvalis. Grodzińs ki \& W under (1975) summarized the data for these three rodents and presented a mean percentage increase of $61 \%$ in respiration over non-reproducing females of the same body size. Therefore, the component (II) was used as a correction factor for the metabolic cost of reproduction.

\section{Field Techniques}

The field work was performed from April 1974 to June 1976. Information concerning density, survival, immigration, age and sex ratios, and weight as well as behavior and microclimate was necessary to test the model. Employing National live-traps $(\# 201)$ baited with peanut butter, raisins and chopped apple, squirrels were trapped, marked and released throughout their active seasons. Each animal was uniquely marked with freeze-brands ( $\mathrm{H} \mathrm{a} \mathrm{do} \mathrm{w,} \mathrm{1972)} \mathrm{and/or} \mathrm{ear} \mathrm{tags} \mathrm{(National}$ Tag Co. size \#1). Each time a squirrel was captured, weight (to nearest 5 grams), total and tail length (to nearest $0.5 \mathrm{~cm}$ ), age, sex, reproductive condition and identification number were recorded. Density (i.e. minimum number known to be alive) was determined by using computer programs provided by $\mathrm{K} \mathrm{re} \mathrm{bs} \mathrm{(1972).}$

Survivorship was determined using a calendar of occurrence. In addition to capture-mark-recapture data, sightings for each individual were compiled on a weekly basis to determine the origin and fate of each individual.

Litter size was obtained in 1975 by counting the number in each litter during the four days after they first appeared above ground. This count is possible because litter mates group together and do not wander away from the nest burrow entrance during this time. The largest count for each of seven litters was used to determine a mean litter size.

Because wind, humidity, radiation and air temperature affect the thermal balance of an animal, operative environmental temperature, as developed by B a kken (1976) and as applied to $S$. richardsonii by B y man (manuscript in prep.), was used as ambient temperature in Wunder's equation. To obtain operative environmental temperature the following data were gathered: 1) air temperature at the soil surface and at $200 \mathrm{~cm}$ above the surface, wind speed at $28 \mathrm{~cm}$ above soil surface, relative humidity, total sky and ground radiation and total solar short wave radiation. Because wind and radiation probably have negligible effects inside the animal's burrow, air temperatures obtained one meter down the tunnel from the entrance were used as ambient temperatures.

In addition the percentage of time spent above ground, the percentage of time spent moving when above ground, and running speed of the squirrels were obtained. Running speed was obtained by timing the movements of individuals among landmarks in the field. Likewise, the percentage of time spent above ground was determined on eight days during the summer of 1976. The number of minutes that an animal spent above ground was recorded for observation sessions which 
lasted from 3.75 to 6.5 hours and encompassed all daylight hours. The percentage of time above ground was converted to the number of hours above ground during a 24-hour day. The percentage of time moving versus not moving was obtained from time budgets of the squirrels activities ( $\mathrm{Z}$ e g e r s, 1977) obtained via metronome timing (W i e $\mathrm{n}$ s et al., 1970).

\section{Laboratory Techniques}

Fifteen individuals from the study area were sacrificed and brought into the laboratory. Each stomach-free carcass was dried and ground separately to a homogeneous mass in alcohol. Then, following standard chemical techniques and using a Labco Goldfisch Extraction Apparatus, lipid was extracted from three randomly selected, 3-gram samples of this material for each individual. Fat index (F. I. $=$ grams fat/grams dry lean weight), percent fat, percent water, percent dry lean weight, and percent dry weight were obtained. In addition, one gram samples of the remaining homogeneous mixture were burned in Parr Oxygen-bomb Calorimeter to determine the caloric value of Richardson's ground squirrel tissue.

\section{RESULTS}

\section{Field Data}

Mean summer density, density at arousal, and density at hibernation were higher in 1974 than 1975 (Table 1). The number of animals lost

Table 1

Densities of Spermophilus richardsonii elegans in a montane meadow ecosystem. Units are number per hectare.

\begin{tabular}{|c|c|c|c|c|c|c|c|c|}
\hline 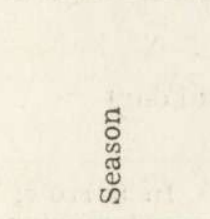 & 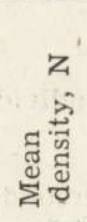 & 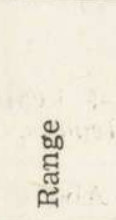 & 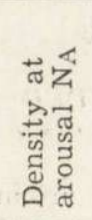 & 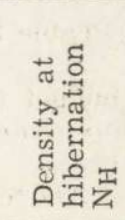 & 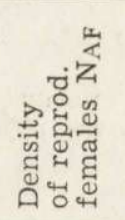 & 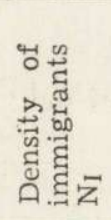 & 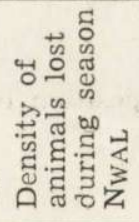 & 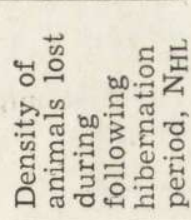 \\
\hline Summer 19 & 35.7 & $24-48$ & 25. & & 20.0 & 5.0 & 22.3 & 9.4 \\
\hline Summer 1975 & 29.9 & $19-49$ & 19.0 & 15.4 & 16.0 & 5.8 & 33.1 & 0.0 \\
\hline
\end{tabular}

during the summer $\left(N_{W A L}\right)$ was greater in 1975 than 1974 . In addition summer survivorship during 1975 was significantly less than that during $1974\left(\chi^{2}=16.98, p \leqslant 0.001\right)$, although survivorship during the winter of $1975-76$ was considerably greater than that during the previous winter $\left(\chi^{2}=12.35, p \leqslant 0.001\right)$ (Table 2$)$.

Mean litter size for 1975 was $5.9(n=7 ; \mathrm{SD}=1.57)$. This compares favorably with mean litter sizes of 3.7 to 8.0 in S.r. richardsonii (Dorrance, 1975; Nellis, 1969), and with mean litter sizes of 5.9 and 7.0 for S.r. elegans (C lark, 1970; Denniston, 1957). 
Pooled data from all three summers gave mean live weight at arousal as 239.0 grams $(n=42 ; \mathrm{SD}=44.1)$, at the onset of hibernation as 296.0 grams $(n=26 ; \mathrm{SD}=51.1)$, and for the entire summer season as 291.3 grams $(\mathrm{n}=118 ; \mathrm{SD}=77.2)$.

Table 2

Survivorship of Spermophilus richardsonii elegans in a Colorado montane meadow from 18 May 1974 to 19 June 1976. Ratios are the number known to be alive at the end of that season in a 1.39 hectare area divided by the total known to exist in that area during that particular season. Percentages are the percentages surviving at the end of that season.

\begin{tabular}{|c|c|c|c|c|c|c|c|c|}
\hline & \multicolumn{4}{|c|}{1974} & \multicolumn{4}{|c|}{1975} \\
\hline & \multicolumn{2}{|c|}{ Summer } & \multicolumn{2}{|c|}{ Winter } & \multicolumn{2}{|c|}{ Summer } & \multicolumn{2}{|c|}{ Winter } \\
\hline & $\%$ & Ratio & $\%$ & Ratio & $\%$ & Ratio & $\%$ & Ratio \\
\hline Adult males & 77.78 & $7 / 9$ & 42.86 & $3 / 7$ & 30.77 & $4 / 13$ & 100.00 & $4 / 4$ \\
\hline Adult females & 64.70 & $22 / 34$ & 72.73 & $16 / 22$ & 32.00 & $8 / 25$ & 100.00 & $\begin{array}{l}8 / 8 \\
8 / 8\end{array}$ \\
\hline Juvenile males & 37.50 & $3 / 8$ & 33.33 & $1 / 3$ & 33.33 & $3 / 9$ & 100.00 & $3 / 3$ \\
\hline Juvenile females & 29.41 & $5 / 17$ & 80.00 & $4 / 5$ & 30.00 & $6 / 20$ & 100.00 & $6 / 6$ \\
\hline Total & 54.41 & $37 / 68$ & 64.86 & $24 / 37$ & 31.34 & $21 / 67$ & 100.00 & $21 / 21$ \\
\hline
\end{tabular}

The remaining data needed for computing $D E B$ are summarized in Table 3. Mean velocity for moving ground squirrels was $5.5 \mathrm{Km} / \mathrm{hr}$ (range 0.47 to $32.4 ; \mathrm{SD}=5.80 ; \mathrm{n}=180$ ); mean operative environmental

Table 3

Composition of daily energy budget $(D E B=35.49 \mathrm{kcal} /$ individual/day) of Spermophilus richardsonii elegans.

\begin{tabular}{lccc}
\hline & $\begin{array}{c}\text { Above ground; Above ground; } \\
\text { not moving }\end{array}$ & $\begin{array}{c}\text { In burrow; } \\
\text { moving }\end{array}$ & not ming \\
\hline Biomas (grams wet wg/indiv.) & 291.3 & 291.3 & 291.3 \\
Velocity (km/hr) & 0.0 & 5.5 & 0.0 \\
Air temp. ( ${ }^{\circ} \mathrm{C}$ ) & 26.2 & 26.2 & 18.8 \\
Metabolic rate (kcal/gm/hr) & 0.00444 & 0.03075 & 0.005 .23 \\
Time spent (hrs/day) & 2.63 & 0.50 & 20.82 \\
Energy expenditure (kcal/indiv./day) & 4.08 & 4.48 & 26.93 \\
\hline
\end{tabular}

temperature was $26.22^{\circ} \mathrm{C}(\mathrm{SD}=13.12 ; \mathrm{n}=30)$. Mean burrow temperature was $18.8^{\circ} \mathrm{C}(\mathrm{SD}=3.409 ; \mathrm{n}=84)$. On the average, $22.19 \%$ of a squirrel's time during daylight hours (i.e. $3.18 \mathrm{hr} /$ day) was spent above ground. The squirrels were moving $15.65 \%$ of their time spent above ground (i.e. $0.5 \mathrm{hr} /$ day). 


\section{Laboratory Data}

Means of $32.7 \%$ dry weight, $66.8 \%$ water, $23.2 \%$ lean dry weight and $9.9 \%$ fat were obtained (Table 4). Caloric value of the tissue was 5.433 $\mathrm{kcal} / \mathrm{gm}$ dry weight (range 4.974 to $5.998 ; \mathrm{SD}=0.36 ; \mathrm{n}=6$ ).

Table 4

\begin{tabular}{|c|c|c|c|}
\hline $\begin{array}{c}\text { Body } \\
\text { Component }\end{array}$ & Mean & Range & $\begin{array}{l}\text { Standard } \\
\text { Deviation }\end{array}$ \\
\hline $\begin{array}{l}\% \text { dry wgt } \\
\% \text { water } \\
\% \text { lean }\end{array}$ & $\begin{array}{l}32.7 \\
66.8\end{array}$ & $\begin{array}{l}23.9-44.1 \\
76.1-55.9\end{array}$ & $\begin{array}{l}8.0 \\
7.9\end{array}$ \\
\hline $\begin{array}{l}\text { dry wgt } \\
\% \text { fat } \\
\text { fat index }\end{array}$ & $\begin{array}{c}23.2 \\
9.9 \\
0.44\end{array}$ & $\begin{array}{r}34.6-18.4 \\
23.9-2.7 \\
1.30-0.13\end{array}$ & $\begin{array}{l}4.8 \\
6.4 \\
0.33\end{array}$ \\
\hline
\end{tabular}

\section{The Model}

Total energy flow during the summer of 1975 (185,046.2 kcal/ha) declined from that of $1974(216,659.0 \mathrm{kcal} / \mathrm{ha})$. The values of all energy parameters decreased in 1975 from 1974 except the energy lost due to dispersal and death $\left(E_{W A L}\right)$ which actually increased (Table 5). During

Table 5

Value for seven energy parameters of a population of Spermophilus richardsonii elegans. Units are $\mathrm{kcal} / \mathrm{ha}$. Symbols are defined in text.

\begin{tabular}{rrrrrrrr}
\hline Year & \multicolumn{1}{c}{$E_{A}$} & $E_{C}$ & $E_{I}$ & $E_{M}$ & $E_{W A L}$ & $E_{H}$ & $E_{H L}$ \\
\hline 1974 & 10570.3 & 203512.0 & 2576.0 & 191761.6 & 11491.6 & 13405.6 & 5372.0 \\
1975 & 8033.4 & 174023.9 & 2988.9 & 159924.5 & 17057.5 & 8064.2 & 1552.9 \\
1976 & 6511.3 & & & & & & \\
\hline
\end{tabular}

both summers most of the energy utilized was obtained by consumption ( $E_{C}$ equals $93.9 \%$ and $94.0 \%$ of total energy flow in 1974 and 1975 respectively) and lost via metabolism ( $E_{M}=88.5 \%$ and $86.4 \%$ of total flow in 1974 and 1975 respectively). $E_{W A L}$ accounted for $5.3 \%$ and $9.2 \%$ of total energy flow. Only $6.2 \%$ of total flow in 1974 and $4.4 \%$ in 1975 was retained by the population as it entered hibernation $\left(E_{H}\right)$. In $1974 E_{A}$ 
accounted for $4.9 \%$; this was $4.3 \%$ in 1975 . Immigration contributed the least to total flow, $1.2 \%$ in 1974 and $1.6 \%$ in 1975.

\section{DISCUSSION}

\section{Analysis of the Model}

We devised a model of energy flow different from most other models of small mammal populations. Most energy flow models are based largely on a physiological analogy in which energy flow at the populational level is equated with that at the organismic level. Thus, a population has production, consumption, respiration, and assimilation as does the individual. Furthermore, O d u m's (1971) universal model of energy flow was designed to be applicable at the organismic, populational, and ecosystem levels.

Our model divides energy flow into different pathways. That values for all the energy parameters were obtained is evidence that the approach is possible. Moreover, exploitation efficiency and average daily metabolic rate $(A D M R)$ derived from our model compare favorably with those determined, by more conventional techniques, for other small mammals. To compute exploitation efficiency $\left(E_{C} / F_{a} \times 100\right)$ for $S$. richardsonii the food available $\left(F_{a}\right)$ was equated with net primary production of temperate grassland (i.e. $2.556 \times 10^{7} \mathrm{kcal} / \mathrm{ha}$, according to W h it ta$\mathrm{ker}, 1975)$. The close agreement of this efficiency with those of other herbivores (Table 6 ) indicates the accuracy of the $E_{C}$ value we obtained.

Table 6

Exploitation efficiencies for nine species of rodents.

\begin{tabular}{lcl}
\hline \multicolumn{1}{c}{ Species } & $\begin{array}{c}\text { Exploitation } \\
\text { Efficiency }\left(C / F_{a} \times 100\right)\end{array}$ & \multicolumn{1}{c}{ Reference } \\
\hline Clethrionomys glareolus and & & \\
Apodemus flavicollis & $0.6-1.9$ & Ryszkowski, 1969 \\
Microtus agrestis & $1.5-2.8$ & Hansson, 1971 \\
M. oeconomus & .07 & Gebczyńska, 1969 \\
M. agrestis & $2.9-13.7$ & Myllymaki, 1968 \\
M. pennsylvanicus & $0.4-1.6$ & Golley, 1960 \\
M. agrestis and & 1.03 & Grodziński et al., 1966 \\
Pitymys subterraneus & $0.14-0.31$ & Ryszkowski, 1969 \\
A. agrarius & $0.68 \& 0.79$ & This study \\
S. richardsonii & & \\
\hline
\end{tabular}

Since $E_{M}$ is the dominant factor in computing $E_{C}$, errors in the value of $E_{M}$ should be reflected in exploitation efficiency. In addition $A D M R$ calculated from our data is not statistically significantly different from 
the ADMR's of other rodents. Our $A D M R$ lies within the $95 \%$ confidence interval for a 291.3 gram rodent predicted by the linear regression equation for body weight and $A D M R$ presented by French et al. (1976). The apparent accuracy of the exploitation efficiency and $A D M R$ obtained from our data support the validity of our energy flow model.

\section{Energy Flow in a Population of Richardson's Ground Squirrel}

Our model discloses several interesting properties of energy flow in Richardson's ground squirrels, knowledge of which provides insight into the role of this squirrel in its montane meadow ecosystem. First, total energy flow during the summer of 1975 . was only $85.4 \%$ of that in 1974 . Several explanations are possible including decrease in food supply, changes in winter survivorship, and increased predation and/or disease. Decreased food supply seems unlikely. An admittedly subjective appraisal indicated that in 1975 the vegetation was thicker, lusher, and taller, with many more species blooming than in 1974 . Weather conditions may account for this difference in primary production, although it also could be explained by reduced grazing pressure resulting from the decrease in numbers of squirrels in 1975. Climatological data for the Nederland, Colorado weather station (6 miles northwest of and at the same elevation as the study site) show the weather for each summer and its preceding winter to be essentially the same except that the summer of 1974 was cooler and much drier than that of 1975 (U.S. Dept. of Commerce 1974 and 1975). Precipitation from May through August was only 5.73 inches in 1974 compared to 9.03 in 1975 . Indeed, May precipitation in 1974 was only 0.07 inch compared to 2.52 in 1975. Drought during May, critical in the growth of plants, undoubtedly was partially responsible for low primary production in 1974. Food supply may actually have been greater in 1975 than 1974 .

Because survivorship data for the winter of 1973-1974 were not available, the possibility that changes in winter survivorship were responsible for the reduction in total energy flow was not testable. High surivorship over the winter of 1973-74 could have caused the higher arousal density of 1974 than of 1975. This difference could explain the greater energy flow in 1974 than in 1975. The difference in arousal energy $\left(E_{A}\right)$, however, was only $2536.7 \mathrm{kcal}$, which was only $0.8 \%$ of the difference in total energy flow. Mean density, by affecting $E_{M}$, seemed to be the main factor causing the difference in total flow. Therefore, summer survivorship was probably more important in determining total flow than winter survival because mean summer density is more directly dependent on summer survival than on winter survival, 
although winter survival certainly is critical in setting the starting density from which the population may expand.

If total energy flow does depend upon summer survivorship, then the importance of individuals lost to predators, disease, and dispersal (i.e. $N_{W A L}$ and $E_{W A L}$ ) should have been greater in 1975 than 1974, and should have influenced the reduction in total flow in 1975. In fact, the relative importance of $E_{W A L}$ to total flow did increase significantly in 1975 (from $5.3 \%$ to $9.2 \%$ of total flow) while the absolute energy flow increased from $11,491.9 \mathrm{kcal} / \mathrm{ha}$ in 1974 to $17,057.5 \mathrm{kcal} / \mathrm{ha}$ in 1975 (a $48 \%$ increase). This reflects an increase from $22.3 /$ ha to $33.1 /$ ha in number of squirrels lost $\left(N_{W A L}\right)$ and corresponds to a decrease in summer survivorship from $54.4 \%$ to $31.3 \%$ (Tables 1 and 2).

The reduction in total energy flow was due, at least in part, to increased whole animal losses in 1975. Probably both predation (including road kills) and dispersal were involved. Unfortunately, we do not know the fates of those individuals that were lost from the population. Certainly some dispersed. Typically young males are the dispersing individuals. Quanstrom (1968) reported that 33 of 35 road kills were young males, which he presumed were dispersing. Yeat on (1969) found that juvenile males disperse farther than juvenile females. $\mathrm{M}$ ic h e n e r (1972) observed that no females moved more than 150 meters while $85 \%$ of young males and $100 \%$ of adult male movements ranged up to 450 meters. Dispersal, therefore, probably accounted for much of the loss of juveniles.

Predation also seems to affect summer survivorship. Although quantitative data were difficult to obtain, our observations indicate increased predation in 1975. Four instances of successful predation were recorded during 194 and 168 hours of observation in the summers of 1974 and 1975 respectively. All occurred in 1975 with two involving red-tailed hawks (Buteo jamaicensis) and two involving badgers (Taxidea taxus). In addition, badgers were observed in the study area on only one brief (15-minute) occasion in 1974, while they were observed on 17 days in 1975. Often they remained in the field, sunning or hunting, for 3-4 hours at a time. Hence, although avian predators were observed on 25 separate occasions in 1974 and on 20 in 1975, total predation pressure seems to have been greater in 1975 and could have accounted for increased $E_{W A L}$ in 1975.

Another characteristic of energy flow was the decrease of $E_{H}$ in 1975 to only two-thirds of what it was in 1974. In relation to total flow this represents a decline from $6.2 \%$ to $4.4 \%$. This may have been due to increased $E_{W A L}$ during 1975 (Table 5). Energy lost to dispersal and predators consid - rably reduced density at hibernation and thereby reduced 
the energy available for hibernation. In a situation of this sort, immigration $\left(E_{I}\right)$ should increase to fill the void. The observed increase of $412.2 \mathrm{kcal} / \mathrm{ha}$ in $E_{I}$ was not enough, however, to compensate for the $5339.2 \mathrm{kcal} / \mathrm{ha}$ difference in $E_{H}$ between 1974 and 1975 . Because all factors pointed to greater availability of food in 1975 than 1974, food supply probably did not reduce $E_{H}$ in 1975 . Therefore, the decline in $E_{H}$ appears to be due to 1) increased energy losses to dispersal and predation and 2) the inability of immigration to fill the resulting void. The population appears to have been below carrying capacity at hibernation time.

The difference in density at hibernation and the reduction in total energy flow from 1974 to 1975 calls attention to the problem of density regulation in Richardson's ground squirrel. Our results provide information which can be used to assess several hypotheses of population control. Although one factor alone seems unlikely to regulate density, exploring the possible impacts of several factors on density in light of the information generated from the model is worthwhile.

The role of predators in regulating densities of small mammals is controversial (e.g. Krebs \& Myers, 1974). To determine the full interaction between one population of predators and one population of its prey is nearly impossible. Predation is difficult to observe, while food webs are complex and causes of death are many; hence the impact of the predator is obscured. However, predation does seem to reduce populations in peak phase and to hold density at low phase delaying the next increase phase (K r e b s \& M y e r s, 1974). Our population of Richardson's ground squirrels declined from 1974 into the spring of 1976 (Table 5). Possibly predation played an important role in density regulation during that decline. Certainly, as we have noted, the visibility of badgers increased in 1975. Also, the low density of squirrels at arousal in 1976 (15.4/ha compared to $25 /$ ha in 1974) could have been due to heavy predation by badgers the previous summer.

Another hypothesis regarding density control is the effect of weather. Barash (1974), Fuller (1969), and Merritt \& Merritt (in press) presented evidence that weather does influence the density of rodents. Weather certainly could affect the density of S.r. elegans. More favorable snow and temperature conditions during the winter of 197576 compared to the previous winter could have increased survivorship, thereby modifying breeding density and the potential for increase within the population. However, we found no statistically significant differences between the means of the monthly values for mean temperature, mean minimum temperature, degree days, total precipitation, or maximum snow depth (U.S. Dept. of Commerce 1975 and 1976). No data are 
available, unfortunately, on the frequency or severity of thaws and of snow-free periods, both of which are critical in assessing the harshness of the winter for hibernating animals.

Spring weather may also affect density by influencing reproductive success. Z e gers \& Williams (1977) found fat levels (energy reserves) nearly depleted for adult male Richardson's ground squirrels and completely depleted for adult females during the first month after arousal in 1976. Morton (1975) documented a similar situation for $S$. beldingi. Possibly this condition was caused by the energetic costs of reproduction and the minimal supply of food. M ichener (1973) correlated arousal and breeding with increasing daily maximum temperature in late March and early April for S.r. richardsonii. If unseasonably cool spring temperatures delay emergence, and hence breeding, the increased length of hibernation may deplete fat reserves to the point where the energetic costs of reproduction could result in the death or decreased fertility of some individuals.

Another factor influencing density is social interaction. Behavior has been identified as the important density regulating factor for other populations of ground squirrels. Territoriality among breeding females and dispersal of young appear to be dominant regulators for the Arctic ground squirrel (C a r l 1971) and the Uinta ground squirrel (S l a d e \& B a l ph, 1974). Dispersal of young appears to produce a significant reduction in the number of potentially breeding individuals $(\mathrm{M} \mathrm{i} \mathrm{c} \mathrm{h} \mathrm{e-}$ ner, 1972; Ye a to n, 1969). Hence, social organization may inhibit increases in density. Moreover, social organization appears plastic enough to allow population increase when density is low (B a r a s h, 1974; Dorrance, 1975; Slade \& B a l p h, 1974). Therefore, although our model gives no information concerning social interaction as a densityregulating mechanism, data from other populations of sciurids suggest that this is likely to be the case.

Acknowledgements: Financial aid was supplied by Sigma Xi and the Kathy Lichty Memorial Fund of the University of Colorado. Our thanks to Drs. David Chiszar and Guy Steuek for assistance in the statistical analysis of these data. Drs. David Armstrong, Terry Helser, and Willis Ratzlaff made many helpful suggestions when reviewing the manuscript.

\section{REFERENCES}

1. Bakken G. S., 1976: A heat transfer analysis of animals: Unifying concepts and the application of metabolism chamber data to field ecology. J. Theor. Biol., 60: 337-384.

2. Barash D. P., 1974: The evolution of marmot societies: a general theory. Science, 185: 415-420. 
3. Carl E. A., 1971: Population control in Arctic ground squirrels. Ecology, 52: $395-413$.

4. Cla rk T. W., 1970: Richardson's ground squirrel (Spermophilus richardsonii) in the Laramie Basin, 'Wyoming. Great Basin, Wyoming. Great Basin Natur., 30: $55-70$.

5. Denniston R. M., II, 1957: Notes on breeding and size of young in the Richardson ground squirrel. J. Mammal., 38: 414-416.

6. Dorrance M. J., 1975: The annual cycle and population dynamics of Richardson's ground squirrel. Ph. D. Thesis, University of Wisconsin. University Microfilms, Ann Arbor, Mich. (Diss. Abstr. 35 (11): 5386).

7. French N. R., Grant W. E., Grodziński W. \& Swift D. M., 1976: Small mammal energetics in grassland ecosystems. Ecol. Monog., 46: 201-220.

8. Fulle r W. A., 1969: Changes in numbers of three species of small rodents near Great Slave Lake, N. W. T. Canada, 1964-1967, and their significance for general population theory. Ann. Zool. Fenn., 6: 113-144.

9. Gębczyńska Z., 1969: Some parameters of Microtus oeconomus (Pallas, 1976) energetics. [In: „Energy flow through small mamal populations « K. Petrusewicz, L. Ryszkowski eds.]. Polish Sci. Publ.: 123-128. Warszawa.

10. Golley F. B., 1960: Energy dynamics of a food chain of an old-field community. Ecol. Monogr., 30: 187-207.

11. Golley F. B., Ryszkowski I. \& Sokur J. T., 1975: The role of small mammals in temperate forests, grasslands and cultivated fields. [In: "Small mammals: their productivity and population dynamics«, F. B. Golley, K. Petrusewicz, L. Ryszkowski eds.]. Cambridge Univ. Press: 223-242. Cambridge.

12. Grodziński W. \& Górecki A., 1967: Daily energy budgets of small rodents. [In: "Secondary productivity of terrestrial ecosystems «, K. Petrusewicz, ed]. Polish Sci. Publ.: 295-314. Warszawa.

13. Grodziński W., Górecki A., Janas K. \& Migula P., 1966: Effect of rodents on the primary productivity of alpine meadows in Bieszczady Mountains. Acta theriol., 11: 419-431.

14. Grodziński W. \& Wunder B. A., 1975: Ecological energetics of small mammals. [In: "Small mammals: their productivity and population dynamics", F. B. Golley, K. Petrusewicz, L. Ryszkowski eds.]. Cambridge Univ. Press: 173-204. Cambridge.

15. H a dow H. H., 1972: Freeze-branding: a permanent marking technique for pigmented mammals. J. Wildl. Manage., 36: 645-649.

16. Hans s on L., 1971: Estimates of the productivity of small mammals in a south Swedish spruce plantation. Ann. Zool. Fenn., 8: 126.

17. Krebs C. J., 1972: Computer programs for analysis of demographic data from small mammal populations. 17 pp. mimeo.

18. Krebs C. J. \& Myers H., 1974: Population cycles in small mammals. Adv. Ecol. Res., 8: 268-399.

19. Merritt J. F. \& Merritt J. M., 1978: Population ecology and energy relationships of Clethrionomys gapperi in a Colorado subalpine forest. J. Mammal., 59: 576-598.

20. Mi chen er G. R., 1972: Population dynamics of Richardson's ground squirrels. $\mathrm{Ph}$. D. Thesis, University of Saskatchewan. $110 \mathrm{pp}$. University Microfilms, Ann Arbor, Mich. (Diss. Abstr. 34: 995).

21. Michener G. R., 1973: Climatic conditions and breeding in Richardson's. ground squirrel. J. Mammal. 54: 499-503. 
22. Morton M. L., 1975: Seasonal cycles of body weights and lipids in Belding ground squirrels. Bull. Southern California Acad. Sci., 74: 128-143.

23. Myllymäki A., 1969: Productivity of a free-living population of the field vole, Microtus agrestis (L.). [In: „Energy flow through small mammal populations«, K. Petrusewicz, L. Ryszkowski eds.]. Polish Sci. Publ.: 255-266. Warszawa.

24. Nadler C. F., Hoffmann R. S. \& Greer K. R., 1971: Chromosomal divergence during evolution of ground squirrel populations (Rodentia: Spermophilus). Syst. Zool., 20: 298-305.

25. Nellis C. H., 1969: Productivity of Richardson's ground squirrels near Rochester, Alberta. Can. Field-Natur., 83: 246-250.

26. Odum E. P., 1971: Fundamentals of ecology. W. B. Saunders Co.: 1-574. Philadelphia (third ed.).

27. Petrusewicz K. \& Grodziński W., 1975: The role of herbivore consumers in various ecosystems. [In: "Productivity of world ecosvstems*. D. E. Reichle, J. F. Franklin, D. W. Goodall eds.]. Nat. Acad. Sci.: 64-70. Washington, D. C.

28. Quanstrom W. R., 1968: Some aspects of the ethoecology of Richardson's ground squirrel in eastern North Dakota. Ph. D. thesis, Univ. Oklahoma, Norman. $121 \mathrm{pp}$.

29. Ryszkowski L., 1969: Estimates of consumption of rodent populations in differents pine forest ecosystems. [In: "Energy flow through small mammal populations«, K. Petrusewicz, L. Ryszkowski eds.]. Polish Sci. Publ.: 281-289. Warszawa.

30. Slade N. A. \& Balph D. F., 1974: Population ecology of Uinta ground squirrels. Ecology, 55: 989-1003.

31. U.S. Department of Commerce, 1974: Climatological data, Colorado, 1974. U.S. Government Printing Office. Washington, D. C.

32. U. S. Department of Commerce, 1975: Climatological data, Colorado, 1975. U. S. Government Printing Office. Washington, D. C.

33. U. S. Department of Commerce, 1976: Climatological data, Colorado, 1976. U. S. Government Printing Office. Washington, D. C.

34. Whittaker R. H., 1975: Communities and ecosystems. Macmillan Publ. Co.: 1-385. New York (second ed.).

35. Wiens J. A., Martin S. G., Holthaus W. R., \& I wen F. A., 1970: Metronome timing in behavioral ecology studies. Ecology, 51: 350-352.

36. Wunder B. A., 1975: A model for estimating metabolic rate of active or resting mammals. J. Theoret. Biol., 49: 345-354.

37. Y e a t on R. I., 1969: Social behaviour, social organization, and daily and seasonal activity patterns in the Richardson's ground squirrel, Spermophilus richardsonii. M. S. Thesis, Univ. Saskatchewan, $106 \mathrm{pp}$.

38. Z egers D. A., 1977: Energy dynamics and role of Richardson's ground squirrel (Spermophilus richardsonii elegans) in a montane meadow ecosystem. Ph. D. Thesis, Univ. Colorado, Boulder. 177 pp.

39. Zegers D. A. \& Williams O., 1977: Seasonal cycles of body weight and lipids in Richardson's ground squirrel, Spermophilus richardsonii elegans. Acta theriol., 22: $380-383$. 
David A. ZEGERS i Olwen WILLIAMS

\section{PRZEPEYW ENERGII PRZEZ POPULACJE SPERMOPHILUS RICHARDSONII ELEGANS}

\section{Streszczenie}

Na podstawie badań terenowych określono energetyczną rolę Spermophilus richardsonii elegans (Kennicott, 1863) w ekosystemie, od kwietnia 1974 do czerwca 1976. W tym celu opracowano także matematyczny model przepływu energii (Ryc. 1). Stwierdzono, że przepływ energii uległ zniżeniu w okresie badań. Straty energii wynikające $\mathrm{z}$ emigracji, warunków pogodowych lub drapieżnictwa były latem 1975 większe niż w tym samym sezonie 1974 roku. Natomiast takie same straty w okresie hibernacji były niższe zimą 1975/76 niż straty zanotowane poprzedniej zimy (Tabela 2). Przedyskutowano zależności między warunkami pogodowymi, drapieżnictwem, zasobnością pożywienia a przepływem energii (Tabela 5).

Dobowy budżet energetyczny (Tabela 3) dla osobnika o średnim ciężarze ciała wynoszącym 291,3 g wynosi 35,49 kcal. Składa się nań: (1) 4,08 kcal wydatkowanej w czasie spoczynku poza gniazdem, na powierzchni gleby, (2) 4,48 kcal wydatkowanej w okresie ruchliwości na powierzchni, (3) 26,93 kcal zużytkowanej w okresie spoczynku w gnieździe.

Srednia liczebność gryzoni wynosiła latem 35,7 osobnika/ha w 1974 roku i zniżyła się do 29,9 osobnika/ha w 1975 r. Liczebność zwierząt w okresie budzenia się ze snu zimowego zniżyła się z 25,0 osobników w 1974 roku do 19,0 w 1975 roku i 15,4 w 1976 r. (Tabela 1). Omówiono także potencjalne mechanizmy regulacyjne działa. jące $\mathrm{w}$ populacji tego gatunku. 